DOI: 10.34015/2523-4552.2020.3.04

УДК 343.93:340.15:343.85

Шкуратенко О. В., кандидат юридичних наук, доцент, завідувач кафедри історії держави та права Національної академії внутрішніх справ e-mail:kgpp@ukr.net ORCID: 0000-0002-1879-0085

\title{
ПОНЯТТЯ, РОЗВИТОК, ЕТИМОЛОГІЯ ЖАРГОНУ КРИМІНАЛЬНОГО ТА ЙОГО МІСЦЕ В СУБКУЛЬТУРНОМУ ПРОСТОРІ (ІСТОРИКО-ПРАВОВИЙ АСПЕКТ)
}

У статті розглянуто окремі питання такого соціокультурного явища, як кримінальний жаргон та визначено його сутності. Досліджено витоки та основні напрями розповсюдження комунікативного атрибута кримінальної субкультури - жаргону кримінального, або ж діалекту кримінального середовища. Також порушено проблему негативного впливу жаргону кримінального в суспільстві, де він поширюється протягом досить тривалого історичного періоду поспіль.

Ключові слова: субкультура; жаргон кримінальний (арго); кримінальна субкультура; злочинець; кримінальне середовище.

В статье рассматриваются отдельные вопросы такого социокультурного явления как уголовный жаргон и определены его сущности. Исследовано истоки и основные направления распространения жаргона криминального, который известен как диалект криминальной среды. Также поднимается проблема отрицательного влияния уголовного жаргона в обществе, где он распространяется на протяжении весьма длительного исторического периода.

Ключевые слова: субкультура; жаргон уголовный (арго); уголовная субкультура; преступник; уголовная среда.

Постановка проблеми. Одну із центральних позицій в кримінальній субкультурі займає, безперечно, iї мова - «арго», або жаргон кримінальний. За своєю сутністю це явище унікальне, у якійсь мірі феноменальне, що займає чільне місце і роль в середовищі злочинного світу. Понятійну сутність такого явища, як жаргон кримінальний («арго») не можна ототожнювати або обмежувати, роз- глядаючи його лише як соціолект і жаргон крадіїв, за допомогою якого члени злочинного світу ідентифікують себе виокремленою групою, на противагу законослухняній частині суспільства.

Жаргон кримінальний - це мова, лексико-фонетичний склад якої застосовується у всьому злочинному світі. Як явище міжнаціональне, кримінальний жаргон $\epsilon$ загальноприй- 
нятий i абсорбований злочинним середовищем. В цілому, жаргон злочинців дуже об'ємний, динамічний, термінологія якого здатна виходити за межі окремішньої спільноти і знаходити своє розповсюдження та поширення у загальному вжитку.

Визначена проблематика не втрачає своєї актуальності як в зарубіжних дослідженнях, так і в розвідках вітчизняної науки, для визначення методів забезпечення нейтралізації та протидії небезпечного поширення і впливу на суспільство контркультури, та однієї з її важливих складових - кримінального жаргону (арго).

Постановка завдання. Мета даної статті - розглянути окремі питання такого соціокультурного явища, як кримінальний жаргон та визначити його сутності. Дослідити витоки та основні напрями розповсюдження жаргону кримінального; окреслити вагомі складові проблеми поширення і утвердження негативного впливу жаргону кримінального в суспільстві, де він поширюється поспіль досить тривалого історичного періоду.

Аналіз останніх досліджень і публікацій. Над проблематикою сутності кримінальної субкультури та її невід'ємною складовою - кримінальним жаргоном, їх роллю і значенням у суспільстві працювали як вітчизняні, так і зарубіжні науковці, а саме: Ю. Александров, В. Анісімков, Ю. Антонян, Д. Виговський, О. Джужа, В. Дрьомін, А. Закалюк, Д. Корецький, О. Науменко, В. Пирожков, О. Старков, В. Тулегенов, В. Фокс.

Фундаментальною була робота М. Гернета, написана на початку XX ст. $з$ дослідження історії тюрми та психології ув'язнених. Науковець детально вивчив типи пенітенціарних установ царської Росії та проаналізував вплив тюремного ув'язнення на особу ув'язненого. До сьогодні праця є джерелом інформації та довідником у вивченні питань кримінальної субкультури [1]. Окрему площину в вивченні питань розповсюдження кримінального жаргону складають його словники. Лексикографування арго активно розпочалося в XIX - на початку XX ст. як в Західній Європі, так і в Російській імперії. Словники В.Ф. Транхтенберга (1908 р.), В. І. Лєбедєва (1909 р.), В. М. Попова (1912 р.) довгий період слугували за основу лексикографування кримінального жаргону, в подальшому неодноразово доповнювались. В 80-х роках у НьюЙорку видавцем В. Козловським було перевидано більшу частину старих словників. Також вийшло перевидання словника В. Бикова «Русская феня: Словарь современного интержаргона асоциальных элементов».

У сучасний період робота над словниками кримінального жаргону представлена особливо повно російськими кримінологами та психологами: Ю. П. Дубягіним, О. П. Дубягіною, Г.Ф.Смірновим, І. В. Лисак, Ю. Ю. Черкасовай, О. С. Єфімовой.

Не дивлячись на те, що явище поширення кримінального жаргону $\epsilon$ постійним предметом досліджень науковців та представників теорій субкультур, вичерпних напрацювань до загальних висновків та повної систематизації дефініцій, окресленої проблематики, досі немає.

Виклад основного матеріалу. Термін «субкультура» в науковій літературі з'являється в 30-х роках ХX ст. Згодом, в західній науці було вироблено трактування субкультури 
як сукупності норм і цінностей, які не ототожнюються 3 загальноприйнятими нормами в суспільстві, сприяють підтриманню та розвитку способу життя, що різниться від традиційного, унормованого даним суспільством. Як підсистема та сутність культури, субкультура кримінальна $\epsilon$ предметом наукового інтересу багатьох наукових шкіл та почала досліджуватися як явище в останні десятиліття [2, с. 429].

Зарубіжна школа криміналістики, яка представлена працями американського вченого В. Фокса, розглядає так звані «теорії субкультур», в основу яких покладено проблему особи злочинця (психологічний портрет, ставлення до оточення) і лише факультативно групи в цілому. I тому, кримінальна субкультура виражена середовищем, де людина розвивається в групі собі подібних чи зграї, члени якої мають стійку систему цінностей, що відрізняється від загально прийнятої [3, c. 139].

Синонімічним поняттям терміна кримінальна субкультура ряд науковців виділяють окремо термін «асоціальна субкультура», під яким розуміються усі характеристики середовища антигромадської поведінки особи та груп, норми, цінності, традиції, звичаї, звички, спосіб життя асоціальних угрупувань, що регулюють їх поведінку і ставлення до інших осіб. Асоціальна субкультура $\epsilon$ субкультура, норми якої відрізняються від загальносуспільних норм 3 ïх ціннісними орієнтирами. Асоціальні групи характеризуються груповою солідарністю, круговою порукою, бравадою злочинною поведінки, кримінальним жаргоном, підтримкою тюремних та злочинних тра- дицій, ритуалів, низьким рівнем розвитку тощо $[4$, с. 8$]$.

На думку деяких науковців, представники цієї субкультури починають усвідомлювати себе як особливу категорію людей, відмінних від усіх інших. Таке уявлення про себе знаходить підкріплення і в зовнішніх формах поведінки, і в особливостях свідомості, загалом - в їхньому світогляді [5, с. 225].

За існуючою загальноприйнятою концепцією, першим із розробників якої був правник Ю. Александров, в структурі кримінальної субкультури виділяються її наступні складові: жорстка групова ієрархія (стратифікація), тобто встановлення статусу членів злочинного середовища: нанесення татуювань; наявність прозвищ; відмова від суспільного життя; обов'язковість наслідуванню усталених норм та правил, і в той же час присутність системи окремих виключень для осіб, які займають вищі щаблі в злочинній ієрархії; наявність ворогуючих між собою угрупувань, конкуруючих за сфери впливу; комунікативні атрибути, до яких відносяться використання в спілкуванні кримінального жаргону (арго), спеціальних жестів, виступаючих як засіб інформації, спілкування та взаємодії; економічні атрибути: «общак» та принципи надання матеріальної допомоги $\epsilon$ матеріальною базою криміналізації, поширення свого впливу на різні сфери; поширення тюремної лірики, яка виражена, в основному в піснях, віршах та міфологізації; алкоголізм і наркоманія виступають як об'єднуючий засіб та середовище для самоствердження тощо [4, с. 8 -10].

Безперечно, одну із центральних детермінант в кримінальній суб- 
культурі займає інформаційнокомунікативна функція, що застосовується у злочинному середовищі, як засіб спілкування: мова - «арго», або жаргон кримінальний. За своєю сутністю це явище унікальне, а в деякій мірі, навіть феноменальне, так як йому належить одна із провідних ролей в середовищі злочинного світу.

Суто термін $з$ фр. «жаргон»це мова, притаманна певному класу, професії, напр., жаргон музикантів, акторів тощо та переповнена спеціальною термінологією та виразами. Жаргон кримінальний («арго» - фp. argot ) - це соціальний діалект, який виник, розвинувся та існує в середовищі декласованих елементів, в переважній більшості злочинців; має семантико-стилістичні особливості, на противагу літературній мові.

Академік Д. С. Ліхачов, також свого часу проводив дослідження мовного середовища «арго». Він відмічав, що зв'язок, який встановлюється словом, завжди односторонній - це або сигнал, або певне спонукання, тому в основі злочинного мислення знаходиться не відтворення і передача власних думок, а ефект, який буде справлено на оточуючих, де слово виступає як засіб [6, c. 13].

Існують численні гіпотези щодо походження кримінальної мови, найбільш відома 3 них полягає у тому, що в основі кримінального жаргону лежить мова «офеней», дрібних торговців, які задля налагодження тісної комунікації та уникнення розповсюдження необхідної таємної інформації створили власну мову незрозумілу іншим. Щодо підходів до визначення даного поняття, то вони досить варіативні.
Історичні ж джерела, проливають світло на ті факти, що саме в кінці XV-XVI ст. в середньовічній Європі, за правління Карла $V$ з'явилися перші словники злочинного жаргону, наприклад, такий як «Liber Vagatorum» - 1528 рік, за редакцією Мартіна Лютера, де зазначалося, що крадії та жебраки - це стародавні плями в історії всього світу та, ймовірно, за припущеннями, вони існували ще до початку цивілізації, так як і їхня мова. Появу таких словників можна пояснити активним розвитком законів, спрямованих проти бродяжництва, яке і ототожнювалося зі злочинними видами діяльності. Більшість дослідників вважає, що арго увібрав в себе значну кількість слів з професійного жаргону моряків, професійних жебраків, тощо [7, с. 8-10].

У Франції перші згадки про словник арго з'являються в XV ст. та напрочуд популярним стає цілий ряд художніх творів Франсуа Війона, в яких $з$ середини розкривається світ кримінального життя.

У Російській імперії матеріал про умовну лексику бродячих торговців (офеня), з'являється в 50-70-х роках XIX ст. Злодійський жаргон виник під впливом офенського, який по своїй структурі та суті забезпечував спілкування артілей бродячих ремісників. В обох випадках свої інтереси спільноти протиставляли інтересам оточуючого світу.

Уперше систематизовані свідчення про мову різних груп населення в Російській імперії, вніс науковець-лінгвіст Володимир Даль у 1853 р., який визначив причини та закономірності поширення арго. Працюючи над формуванням діалектичного словника, В. Даль розумів, що його робота виконується на за- 
мовлення Особливого секретного комітету, $є$ цілком практичною і не переслідує академічних цілей. Проте робота надзвичайно захопила науковця і через деякий час рукопис було складено. А в передмові до словника В. Даль зазначив, що жаргон кримінальний, це діалектизми які можна назвати «блатною музикою», і протягом тривалого періоду часу її складали жебраки, крадії, шахраї, та інші. «Знать музику - знати цю мову; ходити по музиці - займатися злодійським промислом» [8, с. 134-136]. Упорядкований на замовлення МBC словник, не був опублікований за життя автора.

У більш пізній період, а саме в 1908 р., було опубліковано цікаве видання «Передмова до Словника В. Трахтенберга «Блатна музика (Жаргон тюрми)». Ïї автор, Бодуен де Куртене в Передмові до словника висловлював думку про необхідність та важливість досліджень «таємної мови», «жаргону тюрми», або ж «блатної музики», яка складає достовірний матеріал для психологів, етологів (у роботах з психології та етики), юристів, фольклористів, а особливо для досліджень у лінгвістиці та мовознавстві.

У Передмові до Словника навіть зазначалося, що арго - $є$ одним 3 «говорів», який побутує в суспільстві, але безперечно в своєрідній діалектичній подачі. На титульній сторінці вказувалося, що словник складений за матеріалами, зібраними в пересильних тюрмах: Петербурзькій, Московській, Віленській, Варшавській, Київській, Одеській [9, с. 27]. Науковець Бодуен де Куртене вніс певні корективи в розуміння самого поняття «жаргон тюрми», яке в багатьох випадках, сприймалося надто локально. На його думку, вміщені в словнику терміни були притаманні не лише крадіям та шахраям, але й представникам інших «професій», i всі вони заслуговували «не зневаги, а в більшій мірі, співчуття і розуміння, так як ці грані між злочинним і незлочинним світом дуже розмиті. [9, c. 27].

Бодуен де Куртене, стверджував, що «блатна музика» - це продукт міжнародного спілкування, носії «блатного промислу» і «блатних спеціальностей» належать до всього людства. I завдяки такій комунікативності, «блатна музика» увібрала в себе не стільки запозичені з різних мов слова, скільки - своєрідні асоціації значень, що виникли в чужому середовищі, та разом із тим, хоча і в меншій мірі, й іноземну побудову слів і виразів, а також їх фонетичну оригінальність, яка б не суперечила регіональним мовним особливостям $[10$, c. 13$]$.

Про складові елементи блатної музики можна зазначити, що вони в значній мірі виокремлюються своїм загальнонаціональним корінням. Перш за все, формування блатного словника і його інтернаціональність виявляються в численних запозиченнях $з$ німецької та польської мов, існують дослідження й на підтвердження в арго єврейського коріння, що склало основи жаргону кримінального.

Незважаючи на поширення арго як комунікативного атрибуту в кримінальному середовищі, мова проте не йде про повну загальноприйнятність його термінологічного словника. Навпаки, існувала й існує безперечна різноманітність, особливо залежна від регіональності та кола його застосування. 
Сам термін «блатний» перейшов 3 німецької мови через польський Rotwelch. Німецькою Blatter означає крадій, blat - довірений, згодний на щось, польське blat - приховувач краденого, blatny, blotny - злочинний, тобто те саме, що і в арго блат - злочин, блатний - член злочинного світу. Зазначені лексеми вперше зустрічаються в Словнику В. Ф. Трахтенберга [9, с. 27].

На початок XX ст. відмічалось активне поширення «фені» у середовищі єврейської молоді, серед комерсантів та інтелігенції. А з «пролетарською революцією» i, як наслідок репресіями, що слідували за нею, стало розповсюдження специфічної лексики - блатної фені в самих різних верствах населення СРСР, які раніше не мали навіть уявлення щодо такого явища.

У 20-х роках ХХ ст. у СРСР кримінальний жаргон увійшов у вжиток молодіжного-комсомольці середовища де вважалось, що саме арго межує з мовою пролетаріату. А згодом, у заснованих у період тоталітарнорепресивної системи таборах, «музика» була мовою лагерної зони і нею розмовляли всі - незалежно від «масті» - починаючи від ув'язнених, i закінчуючи слідчими та конвоїрами.

У зазначений період порядок виконання і умови відбування покарання в УСРР, регулював прийнятий ВУЦВК 23 жовтня 1925 р. Виправнотрудовий кодекс УСРР. Прийняття Виправно-трудового кодексу УСРР було зумовлене нагальною потребою виконання керівних положень Основних засад кримінального законодавства СРСР та союзних республік $[11$, c. 421$]$.

У 1934 р. створено загальносоюзний орган народний комісаріат внутрішніх справ (НКВС), у зв'язку з цим відбулися значні реорганізації в місцях позбавлення волі. Для керівництва виправно-трудовими таборами в складі НКВС було створено Головне управління виправнотрудовими таборами знане в радянський період як «ГУЛАГ». Це були прийняті одні з законодавчих актів, які закріплювали тоталітарнорепресивну систему в СРСР. Тільки у вересні 1953 р. ВР СРСР видала Указ, у відповідності з яким Верховному судові надавалось право перегляду за протестами Генерального прокурора рішення колишніх ОДПУ, «трійок» НКВС та «особливої наради» при НКВС-КДБ-МВС СРСР. Тоді ж було скасовано військові трибунали, «особливу нараду», а також постанову ЦВК СРСР від 01.12.1934 р. «Про порядок ведення справ про підготовку або здійснення терористичних актів» [12, с. 371-372].

Науковець П. М. Корявцев виділяє декілька етапів поширення в СРСР кримінального жаргону (арго), які пов'язує з «червоним терором» та масовими репресіями, де «політичні» в'язні, повертаючись з місць позбавлення волі до звичайного життя, вносили в соціум незвичну тюремну лексику. В результаті багатьма, у тому числі й діячами культури, блатна феня уже не сприймалась як чисто кримінальний жаргон, а похідні значення термінів дещо забувалися, а самі слова видозмінювалися [13, c. 10].

У радянський період через табори пройшла значна кількість представників усіх верств населення, серед яких були представники культурної еліти, саме вони в подальшому відтворили в своїх творах побут та мову «арго». Кримінальний жаргон 
так поширився і вплівся у лексику радянського населення, що ідеологами всесоюзної влади неодноразово проводилася боротьба з функціональністю такого явища, «арго». Тим само викликає великий інтерес у науковців етимологія кримінального жаргону, де слова, коріння яких сягають вікової історії, поєднуються 3 лагерним радянським «новоязом».

Останній етап популяризації арго, на думку П. М. Корявцева, припадає на 90-і роки XX ст., коли в суспільстві стало модно підкреслювати свою причетність до так званих кримінальних угрупувань, члени яких крадії та злочинці, ставали популярними персонажами масової культури, і в багатьох випадках такі типажі обиралися зразком для наслідування, особливо серед молоді $[13$, с. 10].

Отже, можна стверджувати, що питання консолідації і ототожнення тюремно-табірно-блатного жаргону де, безумовно, тюремний жаргон як мовна традиція кримінального середовища існував багато десятків років, існує і дотепер.

Оскільки жаргон блатний або «феня» знаходиться в постійному розвитку, нараховується близько 15000 лексем та його словосполучень. В основному це слова, які вказують на предмети, признаки та дії, пов'язані із злочинною діяльність та тюремним побутом [14, с. 13].

В арго можна виділити окремі щаблі: лексеми та вирази, які вживаються в однаковій мірі і в кримінальному і в тюремному жаргоні; основною частиною «арго» $є$ кримінальний жаргон, з якого, на думку науковця В.В. Тулегенова, виділяється жаргон професійних злочинців, жаргон представників організованої злочинності, жаргон сутенерів, повій, наркоманів, неповнолітніх, тощо. До особливого виду кримінального жаргону В.В. Тулегенов відносить тюремний жаргон [15, с. 34].

Однак в дослідницьких колах мали місце різні твердження щодо відмінностей або ж тотожностей жаргону кримінального і жаргону тюремного. Звісно, поставали й питання щодо внесення існуючих лексем арго до одного чи різних типів словників. Проте, вочевидь, саме кримінальний жаргон, вміщує лексеми та вирази представників різних кіл кримінального світу, на прикладі словника В. Бикова [16].

Причини існування кримінального жаргону, на думку дослідника кримінальної субкультури Ю. Дубягіна, полягають, перш за все у збоченій психології злочинців-рецидивістів, сутність якої характеризується їх особливостями $[17$, с. 4$]$. Вправно створюючи і нав'язуванні собі i оточенню думки про свою виключність, окремішність, несхожість та превалювання над іншими, злочинне середовище вправно сприяє розповсюдженню хибної думки в соціумі про замкненість і утаємниченість своїх угрупувань і своїх авторитетів.

Однією із функцій кримінального жаргону є ідентифікація представників свого середовища, а в деяких випадках навіть викриття осіб, інфільтрованих правоохоронними органами в кримінальне середовище. Зазвичай, особи, які видавали себе за крадіїв в законі та інших авторитетів або проникали в кримінальне середовище для виконання певних дій, неочікувано могли «провалитися» саме на екзамені з блатної фені [17, c. 7].

Так як саме жаргон кримінальний, або «феня» забезпечує спілку- 
вання в середовищі кримінальних спільнот, головним завданням стає шифрування інформації, щоб «непосвячений» не міг зрозуміти про що йде мова або зрозумів невірно. В кримінальному жаргоні досить велика кількість синонімів, і одне поняття може позначатися десятками різних слів. Більшість термінів, що використовуються у злочинному середовищі, вказують на засоби злочинної діяльності, способи уникнення переслідування, поведінку в суді, характер злочинної діяльності, суб'єкти та об'єкти злочинів.

Зміни які відбуваються в соціальному середовищі, відображаються і в лексемах кримінального жаргону. Як приклад, виникнення нової «професії» - найманий вбивця, сприяло поширенню в лексиці слова «кілер», хоча сам термін запозичене з англійської мови; необхідність для певних осіб особливого, неправомірного захисту своїх інтересів у бізнесі, нерухомості, тощо, дала поштовх введення такого поняття як «криша» i «кришувати», тобто надавати захист певного роду.

Кримінальний жаргон у якійсь мірі виступає класифікатором в злочинній ієрархії, оскільки кожна каста або «масть» має свою власну назву та притаманну їй специфіку, що також відображається у словниках. Засуджені, як правило, відносяться до певної касти, а отже, відразу мають своє визначене положення у злочинній ієрархії де цілком точно прогнозується поведінка даної особи в місцях позбавлення волі.

Кримінальний жаргон активно розповсюджується в середовищі неповнолітніх через його виразність, образність, утаємниченість, романтизм тощо. Кримінальному жаргону властива певна саркастичність та іронічність: «доцент» - нерозумна людина, «коронація» - введення злочинця в звання крадія в законі, «акваріум» - ізолятор тимчасового утримання, «апельсин» - злодій в законі, який купив свій статус. Проте жодне слово з кримінального жаргону не здатне розкрити будь-який новий для злочинця зміст, воно лише вказує на факт.

В кримінальному середовищі недопустимо вживання лайливих слів щодо злочинця, в багатьох випадках це може бути «змито» лише кров'ю. Не менш характерними явищами в злочинному середовищі $\epsilon$ «божба» (клятва) та вживання не лайливих «блатних» слів - вихваляння, як важливий елемент ототожнення і виокремлення особи з ряду всіх інших.

Значима частина лексемів кримінального жаргону використовується в артефактах, безпосередньо для означення предметів, створених спеціально для функціонування в системі підкультур. До таких артефактів відноситься тюремна лірика, блатні пісні, усна проза тощо [14, c. 128].

Висновки. Розвиток кримінального жаргону безперечно у повній мірі пов'язаний з розвитком пенітенціарних установ та кримінального середовища, він $є$ невід'ємним атрибутом кримінальної субкультури. Проблеми боротьби із злочинністю, ефективних шляхів стримування та зменшення її негативних наслідків постають у пошуках і розробках дослідників. В основі концепцій попередження злочинності традиційно лежать теорії, які пояснюють причини злочинної поведінки. А світова глобалізація, розвиток комунікації за 
допомогою всесвітньої мережі Інтернет розмили кордони як культурного так і субкультурного простору.

Отже, для всебічної протидії поширенню атрибутів кримінальної субкультури в суспільстві, необхідним є подальше вивчення закономірностей розвитку, функціонування та етимології кримінального жаргону (арго), фені.

\section{Список використаних джерел}

1. Гернет М.H. История царской тюрьмы: В 5 т. Москва : 1925 URL: https://istoriki.su/uploads/Gernet_M_N_Istoria_tsarskoy_tyurmy_V_pyati_tomakh_Izd_3e_Tom_5_Shlisselburgskaya_katorzhnaya_tyurma_i_Orlovskiy_katorzhny_tse.pdf (дата звернення: 04.09.2020).

2. Шкуратенко О. В. Субкультура кримінальна (стаття) Велика українська юридична енциклопедія : у 20 т. Т. 18 : Кримінологія. Кримінально-виконавче право / редкол.: В.І. Шакун (голова), В.І. Тимошенко (Заст. голови) та ін.; Нац. Акад. прав. наук України ; Ін-т держави і права ім. В.М. Корецького НАН України ; Нац. юрид. ун-т ім. Ярослава Мудрого. Харків : Право, 2019. 544 с.

3. Фокс В. Введение в криминологию. Москва : Прогресс, 1980. 310 с.

4. Александров Ю. К. Очерки криминальной субкультуры. Москва : «Права человека», 2001.152 с.

5. Денисов С. Ф. Кримінальна субкультура як можливий комплекс ціннісних детермінантів у формуванні поведінки особи молодіжного віку. Південноукраїнський правничий часопис. №2. 2009. С. 253-256; Пугач В.О., Непочатова О.В. Кримінальна субкультура та поширення ії в Україні. Вісник кримінологічної асоціації України. Альманах. Вип.1. Харків : Вид-во НУВС, 2004. С. 144-148.

6. Лихачев Д. С. «Черты первобытного примитивизма воровской речи». Язык и мышление-Le langage et la mentalité, № III-IV, Москва-Ленинград : Издательство Академии Наук СССР, 1935, С. 47-100.

7. Михаель Дан. «Язык раввинов и воров хохумлойшен» URL: http://www.berkovich-zametki.com/Nomer23/Michael1.htm (дата звернення: 01.09.2020).

8. Даль В. И. Условный язик петербургских мошенников, известный под. именем «музики» или байкового язика. Вопросы языкознания. 1990. № 1. С. 132-154.

9. Николаева Т. М. Бодуэн де Куртенэ - редактор Словаря В. Ф. Трахтенберга «Блатная музыка («Жаргон» тюрмы)». Русская и сопоставительная филология. Казань, 2004. С. 176-181.

10. Бодуэн де Куртенэ И. А. Предисловие к словарю В. Ф. Трахтенберга «Блатная музыка («Жаргон» тюрмы)». СПб, 1908. 32 с.

11. Історія держави та права України: підручник: у 2-х т. / за редакц. В.Я. Тація, А.Й. Рогожина. Т. 1. Київ : Вид. дім «Ін Юре», 2000. 580 с.

12. Білас I. Г. Репресивно-каральна система в Україні 1917-1953: суспільнополітичний та історико-правовий аналіз : у 2-х кн. Київ : Либідь,1994. 428 с.

13. Корявцев П. М. Отдельные вопросы этимологии блатной фени. Теория антисистем. Источники и документы. C-Пб, 2006 URL: http://antisys.ru/bf.html (дата звернення: 04.09.2020).

14. Ефимова Е. С. Современная тюрьма: быт, традиции и фольклор. Москва: ОГИ, 2004.398с.

15. Корецкий Д. А., Тулегенов В. В. Теория и практика уголовного права и уголовного процесса СПб.: Издательство Р. Асланова "Юридический центр Пресс", 2006. $241 \mathrm{c.}$ 
16. Быков В. Русская феня: Словарь современого интержаргона асоциальных элементов. Specimina philologiae Slavicae. Munchen: Otto Sagner, 1992. 184 c.

17. Дубягин Ю. П., Теплицкий Е. А. Краткий англо-русский и русско-английский словарь уголовного жаргона. Москва : Терра, 1993. 740 с.

\section{References}

Gernet, M.N. (1925). Istoriya carskoj tyurmy. V 5 t. Moskva [in Russian].

Shkuratenko, O. V. (2019). Subkultura kriminalna (stattya) Velika ukrayinska yuridichna enciklopediya: u 20 t. T. 18: Kriminologiya. Kriminalno-vikonavche pravo / redkol.: V. I. Shakun (golova), V. I. Timoshenko (Zast. golovi) ta in.; Nac. Akad. prav. nauk Ukrayini ; In-t derzhavi i prava im. V.M. Koreckogo NAN Ukrayini; Nac. yurid. un-t im. Yaroslava Mudrogo. Harkiv: Pravo [in Ukrainian].

Foks, V. (1980). Vvedenie v kriminologiyu. Moskva: Progress [in Russian].

Aleksandrov, Yu. K. (2001). Ocherki kriminalnoj subkultury. Moskva: «Prava cheloveka» [in Russian].

Denisov, S. F. (2009). Kriminalna subkultura yak mozhlivij kompleks cinnisnih determinantiv u formuvanni povedinki osobi molodizhnogo viku. Pivdennoukrayinskij pravnichij chasopis, 2, 253-256 [in Ukrainian].

Pugach, V. O., Nepochatova, O. V. (2004). Kriminalna subkultura ta poshirennya yiyi v Ukrayini. Visnik kriminologichnoyi asociaciyi Ukrayini. Almanah. Vip.1. Harkiv: Vid-vo NUVS, 144-148 [in Ukrainian].

Lihachev, D. S. (1935). «Cherty pervobytnogo primitivizma vorovskoj rechi». Yazyk $i$ myshlenie-Le langage et la mentalite, III-IV, Moskva-Leningrad: Izdatelstvo Akademii Nauk SSSR, 47-100 [in Russian].

Mihael, Dan. «Yazyk ravvinov i vorov hohumlojshen» URL:http://www.berkovichzametki.com/Nomer23/Michael1.htm (data zvernennya: 01.09.2020) [in Russian].

Dal, V. I. (1990). Uslovnyj yazik peterburgskih moshennikov, izvestnyj pod. imenem «muziki» ili bajkovogo yazika. Voprosy yazykoznaniya, 1, 132-154 [in Russian].

Nikolaeva, T. M. (2004). Boduen de Kurtene - redaktor Slovarya V. F. Trahtenberga «Blatnaya muzyka («Zhargon» tyurmy)». Russkaya i sopostavitelnaya filologiya. Kazan, 176181 [in Russian].

Istoriya derzhavi ta prava Ukrayini (2000). za redakc. V. Ya. Taciya, A. J. Rogozhina. T. 1. Kiyiv: Vid. dim «In Yure» [in Ukrainian].

Bilas, I. G. (1994). Represivno-karalna sistema v Ukrayini 1917-1953: suspilnopolitichnij ta istoriko-pravovij analiz: u 2-h kn. Kiyiv[in Ukrainian].

Koryavcev, P. M. (2006). Otdelnye voprosy etimologii blatnoj feni. Teoriya antisistem. Istochniki i dokumenty. URL: http://antisys.ru/bf.html (data zvernennya: 04.09.2020) [in Russian]. Russian].

Efimova, E. S. (2004). Sovremennaya tyurma: byt, tradicii i folklor. Moskva: OGI [in

Koreckij, D. A., Tulegenov, V. V. (2006). Teoriya i praktika ugolovnogo prava $i$ ugolovnogo processa. SPb.: Izdatelstvo R. Aslanova "Yuridicheskij centr Press" [in Russian].

Bykov, V. (1992). Russkaya fenya: Slovar sovremenogo interzhargona asocialnyh elementov. Specimina philologiae Slavicae. Munchen: Otto Sagner [in Russian].

Dubyagin, Yu. P., Teplickij E. A. (1993). Kratkij anglo-russkij i russko-anglijskij slovar ugolovnogo zhargona. Moskva: Terra [in Russian]. 
0. Shkuratenko, PhD, Associate Professor, Head of the Departmen of History of State and Law on National Academy of Internal Affairs

e-mail: kgpp@ukr.net; ORCID:0000-0002-1879-0085

\section{Definition, development, etymology of criminal jargon and its place in subcultural area (historical and legal aspect)}

This article considers such a socio-cultural phenomenon as a criminal jargon and defines its nature. Sources and main directions of spreading of communicative attribute of criminal subculture - criminal jargon or a dialect of criminal society and definition of its nature are researched. Also, the problem of negative influence caused to society by jargon, where it is expanding during a long historical period is raised.

One of the central positions in criminal society is occupied by its language «argot», or criminal jargon. By its nature this phenomenon is unique and placed in the dominant position with an important role in a criminal society. Conceptual essence of such a phenomenon as criminal jargon shouldn't be limited by identifying it as a sociolect or a language of thieves, by means of which members of criminal society identify each other as a separated group on the contrary to law-abiding part of society.

Criminal jargon is a language which lexical and phonetic structures are used all over the criminal world. As a multinational phenomenon criminal jargon is conventional and absorbed by criminal society. In general, criminal jargon is volumetric, dynamic, its terminology is able to cross the borders of a certain group and seek its prevalence in the common usage.

Defined problematic do not lose its relevance both in the foreign and national researches and is devoted to determination of methods of insurances such as: neutralization and resistance to negative influence on society caused by counterculture and its main part - criminal jargon (argot).

Keywords: subculture; criminal jargon (argot); criminal subculture; criminal society. 